${ }^{1}$ Харківський національний аграрний університет ім. В. В. Докучаєва

${ }^{2}$ Харківський національний університет імені В. Н. Каразіна ${ }^{3}$ ННЦ «Інститут трунтознавства та агрохімії імені О. Н. Соколовського» Україна

\title{
ЕКОЛОГО-ЕКОНОМІЧНА ЕФЕКТИВНІСТЬ ЗРОШУВАЛЬНИХ ПРОЄКТІВ У КОНТЕКСТІ ЗМІН КЛІМАТУ
}

Мета. Мета статті полягає в презентації результатів дослідження щзодо оцінювання еколого-економічної ефективності реалізаџії меліоративних проєктів з урахуванням якості зрошувальної води (на прикладі конкретних проєктів у трунтово-кліматичних умовах Харківської та Донецької областей).

Методологія / методика / підхід. Методологія проведеного дослідження трунтується на використанні міждисциплінарного підходу. У процесі дослідження використано такі методи: монографічний (для узагальнення методологічного та практичного досвіду застосування зрошувальних проєктів); лабораторно-аналітичний (для визначення показників якості зрошувальної води); конструктивно-розрахунковий (під час обчислення показників економічної ефективності приросту врожайності в умовах зрошення); метод Монте-Карло (для імітаиійного моделювання врожайності сільськогосподарських культур без зрошення та в умовах зрошення); статистичний (дисперсійний аналіз) (для оцінювання достовірності отриманих результатів); узагальнення (для підведення проміжних $і$ загальних підсумків еколого-економічного аналізу експериментальних і модельних даних).

Результати. У результаті лабораторного аналізу здійснено оцінку якості води, яка може бути використана для зрошення. Обтрунтовано переваги проєкту організації виробництва аграрної продукиї в умовах краплинного зрошення, очүінено інвестииійну привабливість иього проєкту. Доведено, що застосування краплинного зрошення сприяє зростанню не лиме економічного ефекту, а й адаптації до зміни клімату. Здійснено оцінку економічної ефективності застосування зрошення в землеробстві, зокрема обмежено придатною водою, під час вирощування різних сільськогосподарських культур. 3 огляду на економічну оцінку, вирощування більшості сільськогосподарських культур в умовах зрошення обмежено придатною водою виявилося малоефективним.

Оригінальність / наукова новизна. Наукова новизна роботи полягає в тому, що дістали дальшого розвитку положення щуодо еколого-економічної ефективності застосування меліоративних проєктів з урахуванням якості зрошувальної води. Це одна $з$ перших публікацій, що присвячена економічному управлінню зрошувальними проєктами в аграрному виробництві України в контексті змін клімату.

Практична цінність / значущість. Результати дослідження дозволяють зробити висновки щодо ефективності впровадження проєктів краплинного зрошення, ураховуючи можливі економічні ризики та очікувані вигоди. Результати імітаційного моделювання врожайності сільськогосподарських культур в умовах зрошення можуть бути використані аграрними підприємствами для управління проєктними ризиками.

Ключові слова: ефективність проєкту, вартість проєкту, інновація, якість зрошувальної води, урожайність, Украӥна. 


\section{Lesia Kucher ${ }^{1}$, Serhii Drokin ${ }^{2}$, Yevhenii Ulko ${ }^{1,3}$}

${ }^{1}$ Kharkiv National Agrarian University named after V. V. Dokuchayev

${ }^{2}$ V. N. Karazin Kharkiv National University

${ }^{3}$ NSC «Institute for Soil Science and Agrochemistry Research named after O. N. Sokolovsky»

Ukraine

\section{ECOLOGICAL-ECONOMIC EFFICIENCY OF IRRIGATION PROJECTS IN THE CONTEXT OF CLIMATE CHANGE}

Purpose. The purpose of the paper is to present the results of research on the assessing of the ecological-economic efficiency of the implementation of reclamation projects taking into account the quality of irrigation water (on an example of the specific projects under soil-and-climatic conditions of Kharkiv and Donetsk regions).

Methodology / approach. The research methodology is based on the use of an interdisciplinary approach. The study used the following methods: monographic (to generalize methodological and practical experience in the use of irrigation projects); laboratory-analytical (to determine the quality indicators of irrigation water); constructive-calculated (for calculating the indicators of economic efficiency of yield growth under irrigation conditions); Monte Carlo method (for simulation of crop yields without irrigation and under irrigation conditions); statistical (analysis of variance) (to assess the reliability of the results); generalizations (to summarize the intermediate and general results of ecological-economic analysis of experimental and model data).

Results. As a result of laboratory analysis, water quality was assessed, which can be used for irrigation. The advantages of the project of organization of agricultural production under the conditions of drip irrigation are substantiated, and the investment attractiveness of this project was estimated. It is proved that the use of drip irrigation contributes not only to the economic effect, but also to adaptation to climate change. The economic efficiency of irrigation in agriculture, in particular, limited to suitable water (low quality) during the cultivation of various crops, was evaluated. Given the economic assessment, the cultivation of most crops under irrigated conditions with limited suitable water is ineffective.

Originality / scientific novelty. The scientific novelty of the paper is that the provisions on ecological and economic efficiency of reclamation projects taking into account the quality of irrigation water has been further developed. This is one of the first paper devoted to the economic management of irrigation projects in Ukrainian agriculture in the context of climate change.

Practical value / implications. The results of the study allow to draw conclusions about the effectiveness of the implementation of drip irrigation projects, taking into account potential economic risks and expected benefits. The results of simulation modeling of crop yields under irrigation conditions can be used by agricultural enterprises to manage project risks. Ukraine.

Key words: project efficiency, project cost, innovation, irrigation water quality, yield,

Постановка проблеми. В умовах глобальних кліматичних змін зростає потреба в розробці та залученні методів раціонального природокористування задля заощадження електроенергії, водних та інших природних ресурсів, що використовують у процесі виробництва агропродовольчої продукції. Технології 


\section{Agricultural and Resource Economics}

www.are-journal.com

краплинного зрошення мають істотні переваги порівняно 3 іншими методами іригації грунтів, а їх використання сприяє підвищенню показників урожайності основних сільськогосподарських культур і дозволяє досягати відносно високих показників урожайності. Варто зазначити, що процес краплинного зрошення відбувається за мінімальних витрат зрошуваної води. Ураховуючи високий потенціал розвитку сільського господарства в Україні та зростання попиту на продукцію агросектора у світі, залучення технологій краплинного зрошення $\epsilon$ перспективним напрямом раціоналізації методів ведення сільського господарства та оптимізації витрат під час реалізації проєктів. Актуальність проблеми зумовлена тим, що за інтенсивністю впровадження проєктів краплинного зрошення Україна відстає від багатьох інших країн світу, маючи істотні переваги з огляду на своє географічне положення, кліматичні умови та земельні ресурси. В останні роки спостерігається збільшення тривалості періодів посухи, що призводить до зростання потреб у раціональному використанні водних ресурсів, ураховуючи їх дефіцит у світі, зокрема, й на території України. Отже, 3 іншого боку, актуальність теми дослідження зумовлена змінами клімату в напрямі потепління та перспективою розвитку й запровадження систем краплинного зрошення, ураховуючи основні переваги цього методу іригації в процесі вирощування основних агрокультур в умовах обмеженої кількості прісної води, придатної для зрошення. Тому проведення відповідних досліджень у цій сфері нині $є$ вкрай доцільним та актуальним в умовах посилення світової економічної кризи, глобальної зміни клімату та зростання екологічних проблем, зумовлених господарською діяльністю.

Аналіз останніх досліджень і публікацій. Питанням управління проєктами в аграрному виробництві присвячені праці багатьох учених. Так, економічні аспекти управління аграрними проєктами досліджували A. FuentesPenna, J. A. Ruiz-Vanoye, O. Díaz-Parra [1], Л. Кучер [2; 3], О. Присяжнюк, М. Плотнікова [4], В. Тимочко, Р. Падюка [5]. Питання, що пов'язані 3 органічними аграрними проєктами, розкриті в працях Л. Кучер, М. Хелдак, А. Орленка [6], Р. Салимбаєвої [7] Т. Фесенко, Г. Фесенко, Г. Фесенко [8]; своєю чергою, P. Rani, A. Singh досліджували проєкти зрошення [9]. Дослідження, що присвячені методам оцінювання ефективності упровадження проєктів і проєктного управління, висвітлені в працях А. Кучера, О. Анісімової, М. Хелдак, Є. Улька [10-14].

Питання крапельного зрошення в контексті теорії управління та концепції збалансованого природокористування висвітлено в працях В. Витоптової, H. Бондаренко [15], D. Majumdar [16]. Проблемам зрошення в Україні та розвитку краплинного зрошення зокрема присвячені праці М. Ромащенка та С. Балюка [17; 18]. У цьому контексті важливо зазначити, що актуальність питань зрошення нерозривно пов'язана із проблемою зміни клімату. Ці та інші питання досліджено в працях X. Zou, Y. Li, Q. Gao, Yu. Wan [19], А. Кучера [20]. Проблема дефіциту водних ресурсів, яку лише посилюють зміни клімату, $\epsilon$ актуальною для багатьох країн світу. Це зумовлює вивчення питань 


\section{Agricultural and Resource Economics}

www.are-journal.com

ефективності зрошення та потенціалу економії води [21; 22], впливу зрошення на продуктивність сільськогосподарських угідь у цілому [23], а також ефективності зрошення конкретних сільськогосподарських культур як в Україні [24; 25], так і далеко за ії межами [26-28]. Ефективність застосування системи крапельного зрошення в умовах дефіциту води досліджено в працях Y. Hassani та інших [29], H. Li, J. Zhao [30], при цьому економічну цінність водопостачання для зрошення розкрито в дослідженнях M. Mesa-Juradoa та інших [31], а також F. García Suárez, L. Fulginiti, R. Perrin [32]. Проблему ризиків для сільського господарства через дефіцит води висвітлено в дослідженнях M. Li, W. Xu, T. Zhu [33] та G. Sampson, E. Perry [34]. Зарубіжні вчені також грунтовно досліджують питання підвищення ефективності використання води для зрошення й оптимізації управління цим процесом [3540], у тому числі в аспекті розумного управління водними ресурсами в контексті сільського господарства 4.0 [41], стратегії підвищення врожайності та зниження небезпеки засолення [42], фактори успішності зрошувальних проєктів на основі моделі державно-приватного партнерства [43]. Разом із цим, можливість і доцільність застосування інновацій у зрошуваному землеробстві вимагає зважених дій та одержання чітких експериментальних результатів, оскільки неповнота врахування чинників призводить не лише до економічних втрат конкретних сільськогосподарських товаровиробників, а й безпосередньо завдає екологічний збиток, що відображається на родючості грунтів.

Мета статті полягає в презентації результатів дослідження щодо оцінювання еколого-економічної ефективності реалізації меліоративних проєктів 3 урахуванням якості зрошувальної води (на прикладі конкретних проєктів у грунтово-кліматичних умовах Харківської та Донецької областей).

Виклад основного матеріалу дослідження. Узагальнюючи результати виконаних досліджень і грунтуючись на попередніх розробках одного зі співавторів $[2 ; 3 ; 6]$, на першому етапі запропоновано концептуальну модель управління зрошувальними аграрними проєктами в контексті змін клімату (рис. 1). 3 огляду на нагальну необхідність адаптації агробізнесу до змін клімату, що особливо гостро проявилися в останні роки у формі дефіциту вологи, метою проєктного управління визначено підготовку, прийняття, виконання та контроль рішень щодо підвищення ефективності агровиробництва й адаптації до змін клімату шляхом упровадження зрошувальних проєктів. Ключовими завданнями управління цими проєктами можна вважати такі: розроблення бізнес-плану проєкту; оцінювання ефективності проєкту; пошук джерел фінансування проєкту; обгрунтування й прийняття рішень щодо агроекологічних, гідромеліоративних, техніко-технологічних й організаційноекономічних аспектів реалізації проєкту; оцінка проєктних ризиків. В основу формування концептуальної моделі управління зрошувальними аграрними проєктами варто покласти такі концептуальні ідеї: спрямованість на адаптацію до змін клімату шляхом кліматично розумного сталого землеробства (climatesmart agriculture); зміщення пріоритетів у напрямі індустрії 4.0 (industry 4.0). 


\section{Agricultural and Resource Economics \\ www.are-journal.com}

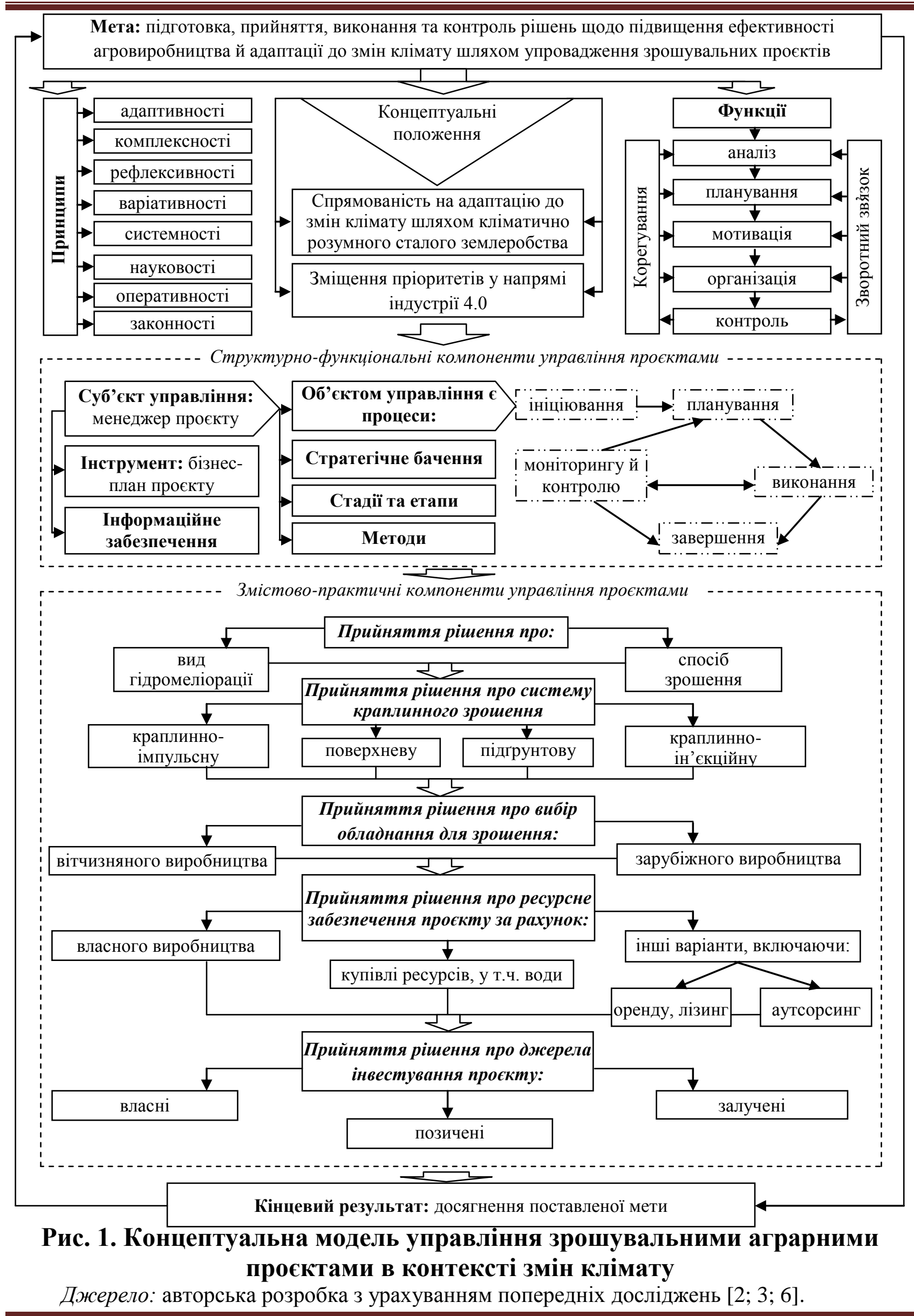




\section{Agricultural and Resource Economics}

www.are-journal.com

У складі запропонованої моделі визначено структурно-функціональні компоненти, які вважаємо сталими, тобто такими, що $є$ приблизно однаковими в будь-якому проєкті, та змістово-практичні компоненти, тобто сукупність конкретних управлінських рішень, характер i зміст яких у кожному конкретному проєкті буде відрізнятися й залежатиме, в першу чергу від того, яку мету і завдання передбачено вирішити. Змістово-практичні компоненти охоплюють відповіді на запитання щодо: виду меліорації (зрошувальні або дренажно-зрошувальні системи) та способу зрошення (дощування, поверхневе, внутрішньогрунтове, крапельне чи лиманне зрошення); системи краплинного зрошення; купівлі обладнання вітчизняного або зарубіжного виробництва; обгрунтування ресурсного забезпечення проєкту може змінюватися (варіювати) залежно від обсягу, джерел фінансування проєкту й ситуаційних особливостей.

3 урахуванням розробленої концептуальної моделі наступний етап нашого дослідження передбачав здійснення модельних прогнозних розрахунків щодо можливості організації ефективного аграрного виробництва в умовах зрошення на прикладі конкретного державного підприємства Національної академії аграрних наук України, що розташоване в Харківській області, шляхом реалізації інвестиційно-інноваційного зрошувального проєкту в цій галузі. Аналіз та узагальнення наявних наукових досліджень і досвіду застосування різних систем і способів зрошення дозволив зробити висновок про те, що на сучасному етапі одним із найбільш перспективних $\epsilon$ краплинне зрошення, оскільки цей спосіб має істотні переваги (у першу чергу, в аспекті ресурсоощадності) порівняно 3 іншими способами іригації. Отже, в основу розроблення проєкту для досліджуваного підприємства пропонуємо покласти технологію краплинного зрошення 3 метою одержання економічного ефекту за одночасного зменшення антропогенного навантаження на екосистему.

Узагальнення результатів визначення сильних i слабких сторін внутрішнього середовища підприємства та встановлення факторів впливу зовнішнього середовища (можливості й загрози) на реалізацію проєкту краплинного зрошення (табл. 1) дало змогу побудувати матрицю прийняття управлінських рішень (табл. 2) щодо: SO - заходів, що варто провести, щоб використовувати сильні сторони для збільшення можливостей проєкту; WO заходів, які варто провести, долаючи слабкі сторони й використовуючи можливості; ST - заходи, які використовують сильні сторони для запобігання загроз; WT - заходи, які мінімізують слабкі сторони для запобігання загроз.

Розробка проєкту системи краплинного зрошення повинна враховувати аналіз джерела зрошення, що передбачає оцінку якості води для краплинного зрошення за агрономічними, екологічними й технічними критеріями відповідно до чинних в Україні національних стандартів. Так, стандарт ДСТУ 7591:2014 «Якість води для краплинного зрошення. Агрономічні, екологічні та технічні критерії» установлює вказані критерії, показники й параметри оцінювання якості природних (поверхневих і підземних) вод для краплинного зрошення. Своєю чергою, ДСТУ 2730:2015 «Захист довкілля. Якість природної води для 
зрошення. Агрономічні критерії» установлює критерії, за якими визначають якість природної води, що використовують для зрошення, за ії впливом на грунти. Відповідно до цього стандарту зрошувальну воду поділяють на три класи: I (придатна), II (обмежено придатна), III (непридатна). Вода I класу може використовуватися для зрошення без жодних обмежень, тоді як використання води II класу передбачає застосування заходів із запобігання деградації грунтів або поліпшення води до I класу. Зрошувальну воду III класу можна використовувати лише після поліпшення показників іï якості до II або I класу.

Таблиия 1

\section{SWOT-аналіз реалізації проскту краплинного зрошення}

Сильні сторони (S)
1) Наявність джерела зрошення в
безпосередній близькості до посівних площ;
2) Розташування в межах населеного пункту
й пряме залізничне сполучення з Харковом;
3) Наявність власної ріллі та виробничої
інфраструктури дослідного господарства;
4) Можливість вирощування органічної
продукції;
5) Економне використання води;
6) Зростання врожайності сільгоспкультур;
7) Зниження рівня забур'яненості території;
8) Скорочення кількості агротехнічних
операцій, пов'язаних із унесенням
агрохімікатів, засобів захисту рослин.
Можливості (O)

1) Зростання попиту на органічну продукцію в Україні та світі;

2) Зростання обсягу експорту окремих видів сільськогосподарської продукції;

3) Додаткові конкурентні переваги через низький рівень розповсюдження технологій краплинного зрошення в Україні;

4) Зниження собівартості продукції та зростання обсягів іiі виробництва шляхом упровадження крапельного поливу;

5) Зменшення рівня водоспоживання;

6) Можливість застосування новітніх розробок завдяки залученню фахових спеціалістів на базі підприємства.

\section{Слабкі сторони (W)}

1) Обмежена кількість потенційних джерел зрошення;

2) Відсутність власної торгівельної мережі та великих потенційних точок збуту в безпосередній близькості від суб'єкта виробництва;

3) Відсутність достатнього обсягу власних джерел фінансування проєкту;

4) Висока вартість обладнання для зрошення та його обслуговування.
1) Відсутність альтернативних джерел зрошення на тлі глобальних кліматичних змін;

2) Зростання витрат на обслуговування обладнання внаслідок можливої девальвації національної валюти або коливань іiі курсу через нестабільну макроекономічну ситуацію в умовах фінансової залежності економіки України від зовнішніх кредитів;

3) Можливе зниження прибутку в разі зменшення купівельної спроможності населення внаслідок девальвації національної валюти або падіння доходів споживачів на внутрішньому ринку;

4) Обмежений доступ на аграрні ринки розвинених країн через різні бар'єри;

5) Нерівні умови конкуренції 3 виробниками агропродукції інших країн через істотні дотації аграрного сектора в ЄС та США.

Джерело: складено авторами з урахуванням аналізу літератури. 
Матриця прийняття управлінських рішень на основі попередніх даних SWOT-аналізу реалізації проскту краплинного зрошення

\begin{tabular}{|c|c|c|}
\hline & Можливості $(\mathbf{O})$ & Загрози (T) \\
\hline $\begin{array}{l}\text { Сильні } \\
\text { сторони }\end{array}$ & 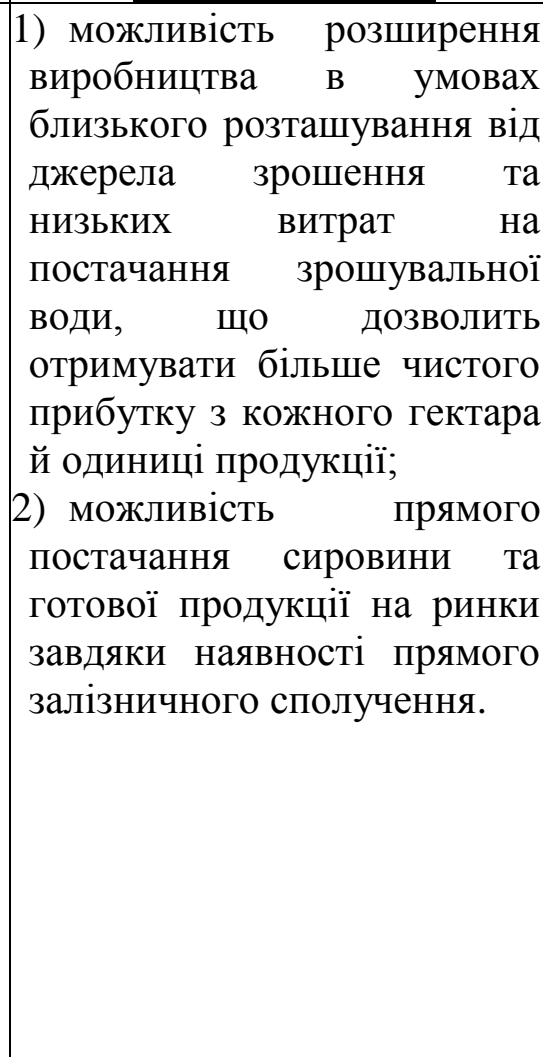 & $\begin{array}{l}\text { 1) кваліфіковані наукові кадри та інфраструктура } \\
\text { дослідного господарства дозволяють здійснювати } \\
\text { науковий моніторинг і розробляти нові рішення в } \\
\text { разі кліматичних змін або проблем із постачанням } \\
\text { зрошувальної води та/або погіршення } \\
\text { макроекономічної ситуації; } \\
\text { 2) вигідне географічне розташування та наявність } \\
\text { прямого залізничного сполучення сприяють } \\
\text { зменшенню витрат на транспортування продукцї } \\
\text { до кінцевого споживача та збереженню норми } \\
\text { прибутку в разі зменшення купівельної } \\
\text { спроможності населення; с сиеціалістів } \\
\text { 3) залучення кваліфікованих } \\
\text { дослідного господарства дає можливість } \\
\text { оперативної переорієнтації виробництва в разі } \\
\text { кон'юнктурних змін на світовому ринку; } \\
\text { 4) пряме залізничне сполучення з Харковом } \\
\text { сприяє зменшенню витрат у процесі поставки } \\
\text { продукції на зовнішні ринки, що робить } \\
\text { підприємство більш конкурентоспроможним в } \\
\text { умовах високої конкуренції на внутрішньому та } \\
\text { світовому ринках. }\end{array}$ \\
\hline$\frac{\frac{\text { Слабкі }}{\text { сторони }}}{\underline{(W)}}$ & 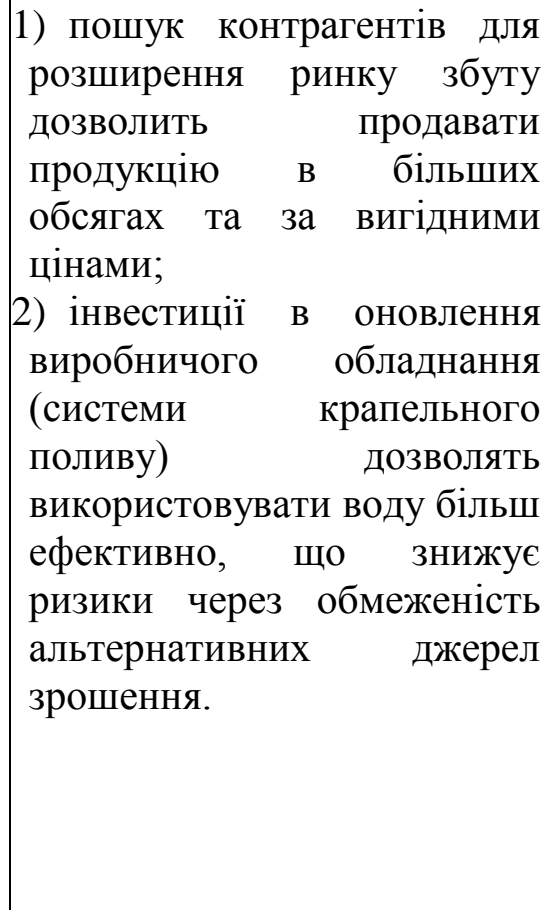 & $\begin{array}{l}\text { 1) обмежена кількість альтернативних джерел } \\
\text { зрошення підвищує ризики, пов’язані } \\
\text { глобальними змінами клімату та конкуренцією } \\
\text { між виробниками агропродукції. Необхідно } \\
\text { займатися пошуком можливих альтернативних } \\
\text { джерел зрошення для зменшення залежності } \\
\text { підприємства від одного джерела; } \\
\text { 2) потреба у встановленні дороговартісного } \\
\text { обладнання для зрошення посилює ризики, які } \\
\text { настають у результаті девальвації національної } \\
\text { валюти або зміни ііі курсу, адже багато } \\
\text { обладнання виробляють в інших країнах, тому } \\
\text { іхня вартість прямо залежить від курсу гривні; } \\
\text { 3) відсутність власної торгівельної мережі та } \\
\text { великих точок збуту у безпосередній близькості } \\
\text { від суб'єкта виробництва істотно підвищує } \\
\text { ризики у разі падіння купівельної спроможності } \\
\text { населення регіону та посилення конкуренції з } \\
\text { боку інших виробників. }\end{array}$ \\
\hline
\end{tabular}

Джерело: складено авторами з урахуванням аналізу літератури.

Узагальнення результатів лабораторного аналізу води (табл. 1), відібраної 3 поверхневого джерела (річки), що розташована в безпосередній близькості від об'єкта дослідження, дало змогу оцінити якість води на предмет відповідності 


\section{Agricultural and Resource Economics \\ www.are-journal.com}

вимогам чинних національних стандартів за основними критеріями. Отже, лабораторний аналіз довів, що за проаналізованими показниками, зокрема вмістом важких металів і фенолів, досліджувана вода відповідає I класу якості й не становить небезпеки для технічного стану систем краплинного зрошення.

Результати лабораторного аналізу води, що потенційно може бути використана для зрошення

\begin{tabular}{|c|c|c|c|c|c|}
\hline Показник & $\begin{array}{c}\text { Одиниця } \\
\text { вимірю- } \\
\text { вання } \\
\end{array}$ & $\begin{array}{c}\text { Результати } \\
\text { визначення } \\
\text { у воді }\end{array}$ & Показник & $\begin{array}{c}\text { Одиниця } \\
\text { вимірю- } \\
\text { вання } \\
\end{array}$ & $\begin{array}{c}\text { Результати } \\
\text { визначення } \\
\text { у воді }\end{array}$ \\
\hline Забарвленість & град. & 45 & Сульфати & МГ/Л & 1097 \\
\hline Каламутність & $\mathrm{HOK}$ & 28,0 & $\begin{array}{l}\text { Вуглекислота } \\
\text { вільна }\end{array}$ & мГ/л & 3 \\
\hline Осад & описово & Присут. & Гідрокарбонати & МГ/Л & 214 \\
\hline Запах, $20^{\circ} \mathrm{C}$ & Бали & 2 & Карбонати & МГ/Л & $<5$ \\
\hline Запах, $60^{\circ} \mathrm{C}$ & Бали & 2 & Амоній & МГ/Л & 7,90 \\
\hline Сухий залишок & МГ/л & 2114 & Нітрати & МГ/Л & 2,4 \\
\hline Мінералізація & МГ/Л & 2221 & Нітрити & МГ/Л & 0,370 \\
\hline Електропровідність & $\mathrm{MKCM} / \mathrm{cm}$ & 3155 & Натрій+Калій & МГ/Л & 400 \\
\hline Редокс-потенціал & MB & 291 & Залізо загальне & МГ/Л & 0,10 \\
\hline $\mathrm{pH}$ & од.pH & 8,3 & Кальцій & МГ/Л & 129 \\
\hline Жорсткість загальна & Ммоль/Л & 12,3 & Магній & МГ/Л & 57 \\
\hline $\begin{array}{l}\text { Жорсткість } \\
\text { карбонатна }\end{array}$ & ммоль/л & 1,9 & Марганець & мГ/л & 0,009 \\
\hline Жорсткість постійна & ммоль/л & 10,4 & Алюміній & МГ/Л & 0,01 \\
\hline Лужність загальна & ммоль/Л & 3,5 & Мідь & МГ/Л & 0,06 \\
\hline Хлориди & МГ/Л & 94 & Феноли & МГ/Л & 0,001 \\
\hline
\end{tabular}

Джерело: сформували автори за результатами лабораторного аналізу.

Отже, в результаті дослідження встановлено, що вода із запропонованого джерела може бути використана для цілей краплинного зрошення. Наступний етап дослідження передбачав економічне обгрунтування ефективності проєкту краплинного зрошення за такими основними дисконтованими показниками: чиста приведена вартість, індекс прибутковості та дисконтований строк окупності. Методика економічного обгрунтування меліоративного проєкту передбачала визначення середніх показників урожайності кожної 3 досліджуваних агрокультур та розрахунку потенційного іiі приросту після встановлення системи краплинного зрошення на основі усереднених багаторічних експериментальних даних. Очікуваний додатковий прибуток розраховано на основі додаткового доходу, який підприємство зможе одержати від приросту врожайності після впровадження систем краплинного зрошення. Амортизацію визначали лінійним методом відповідно до життєвого циклу проєкту, тривалість якого прийнято на рівні п’яти років. Ставку дисконтування розраховували як середньозважене між рентабельністю авансованого капіталу та ставкою кредитування $(22,0 \%)$ з урахуванням прогнозної інфляції $(7,0 \%)$. Рентабельність авансованого капіталу визначено для кожної агрокультури, 


\section{Agricultural and Resource Economics \\ www.are-journal.com}

враховуючи фактичні середні показники. Маркетингове дослідження показало, що станом на 2019 р. середня вартість установлення системи краплинного зрошення становила 5870 грн/га. 3 урахуванням фактичного складу та структури ріллі, а також ринкової кон'юнктури, проєктом передбачено вирощування чотирьох культур (пшениця, соя, соняшник та огірки) на площі 570 га (табл. 4). Прогнозна загальна вартість проєкту становить 3345,9 тис. грн.

Таблиия 4

Проєктні вихідні дані та розрахунок орієнтовної вартості проєкту краплинного зрошення

\begin{tabular}{|l|c|c|c|c|c|}
\hline Культура & $\begin{array}{c}\text { Площа } \\
\text { ріллі, } \\
\text { га }\end{array}$ & $\begin{array}{c}\text { Прогнозний } \\
\text { приріст } \\
\text { урожайності, } \\
\text { т/га }\end{array}$ & $\begin{array}{c}\text { Рівень } \\
\text { рентабельності } \\
\text { авансованого } \\
\text { капіталу, \% }\end{array}$ & $\begin{array}{c}\text { Ставка } \\
\text { дисконту, } \\
\%\end{array}$ & $\begin{array}{c}\text { Прогнозна } \\
\text { вартість проєкту } \\
\text { (сума інвестицій), } \\
\text { тис. грн }\end{array}$ \\
\hline Пшениця озима & 300 & 2,2 & 25 & 30,5 & 1761,0 \\
\hline Соя & 150 & 1,9 & 45 & 40,5 & 880,5 \\
\hline Соняшник & 100 & 1,1 & 110 & 73,0 & 587,0 \\
\hline Огірки & 20 & 15,0 & 100 & 68,0 & 117,4 \\
\hline Усього & 570 & $\mathrm{x}$ & $\mathrm{x}$ & $\mathrm{x}$ & 3345,9 \\
\hline
\end{tabular}

Джерело: авторські розрахунки.

Економічний аналіз узагальнених результатів розрахунку дисконтованих показників орієнтовної економічної ефективності (табл. 5) у цілому свідчить про ефективність запропонованого проєкту краплинного зрошення. Разом із цим, у розрізі конкретних видів продукції аналізовані показники ефективності виявилися доволі відмінними, що вказує на різний рівень інвестиційної привабливості краплинного зрошення. Так, найбільш ефективним може бути проєкт краплинного зрошення огірків, тоді як проєкт краплинного зрошення сої може виявитися неефективним за поточних умов інвестування.

Таблиия 5

\section{Узагальнені результати розрахунку оріснтовної економічної ефективності} проскту краплинного зрошення

\begin{tabular}{|l|c|c|c|c|}
\hline \multicolumn{1}{|c|}{ Культура } & $\begin{array}{c}\text { Чиста приведена } \\
\text { вартість, тис. грн }\end{array}$ & $\begin{array}{c}\text { Чиста приведена } \\
\text { вартість, грн/га }\end{array}$ & $\begin{array}{c}\text { Дисконтований } \\
\text { строк окупності, міс. }\end{array}$ & $\begin{array}{c}\text { Індекс прибут- } \\
\text { ковості, коеф. }\end{array}$ \\
\hline Пшениця озима & 1998,9 & 6660 & 53 & 1,14 \\
\hline Соя & 562,2 & 3748 & 93 & 0,64 \\
\hline Соняшник & 779,3 & 7793 & 45 & 1,33 \\
\hline Огірки & 9195,8 & 22990 & 4 & 78,33 \\
\hline Усього & 12536,2 & 21993 & 16 & 3,75 \\
\hline
\end{tabular}

Джерело: авторські розрахунки.

Отже, результати модельних розрахунків показали екологічну та маркетингову можливість (спроможність) й економічну доцільність реалізації інвестиційно-інноваційного проєкту краплинного зрошення на прикладі вирощування пшениці озимої, соняшника й огірків навіть за умови, що втілення проєкту передбачає залучення інвестицій за рахунок банківського кредиту строком на п’ять років під $22 \%$ річних. Разом із цим, прогнозовані показники економічної ефективності вирощування сої за краплинного зрошення вказують 


\section{Agricultural and Resource Economics \\ www.are-journal.com}

на недостатній рівень ефективності, тому $\epsilon$ потреба в пошуку резервів іiі підвищення або заміні цієї культури на іншу більш інтенсивну, наприклад, кукурудзу. Слід наголосити, що ці результати є попередніми й потребують додаткового обгрунтування на передінвестиційній стадії.

Результати дослідження дозволяють зробити висновки щодо ефективності впровадження проєкта краплинного зрошення, враховуючи можливі екологоекономічні ризики та прибутки, а також позитивний вплив зрошуваної води I класу на стан грунтів і технічних систем зрошення. Використання технологій краплинного зрошення може сприяти зростанню показників урожайності та ощадному споживанню зрошуваної води в умовах зміни клімату, тому такі проєкти можуть бути використані у своїй діяльності як традиційними сільськогосподарськими підприємствами, так і великими агрохолдингами.

На завершальному етапі дослідження здійснено оцінку економічної ефективності застосування зрошення в землеробстві обмежено придатною водою під час вирощування різних сільськогосподарських культур в умовах Донецької області. У цьому випадку 3 урахуванням багаторічних експериментальних даних за допомогою методу Монте-Карло виконано імітаційне моделювання врожайності сільськогосподарських культур за двома проєктними варіантами: 1) без зрошення (без проєкту); 2) в умовах зрошення мінералізованою водою (з проєктом). Результати статистичного аналізу гістограм підтвердили гіпотезу про відповідність модельної вибірки нормальному розподілу врожайності сільськогосподарських культур як у варіанті без проєкту (рис. 2), так й у варіанті з проєктом (рис. 3).

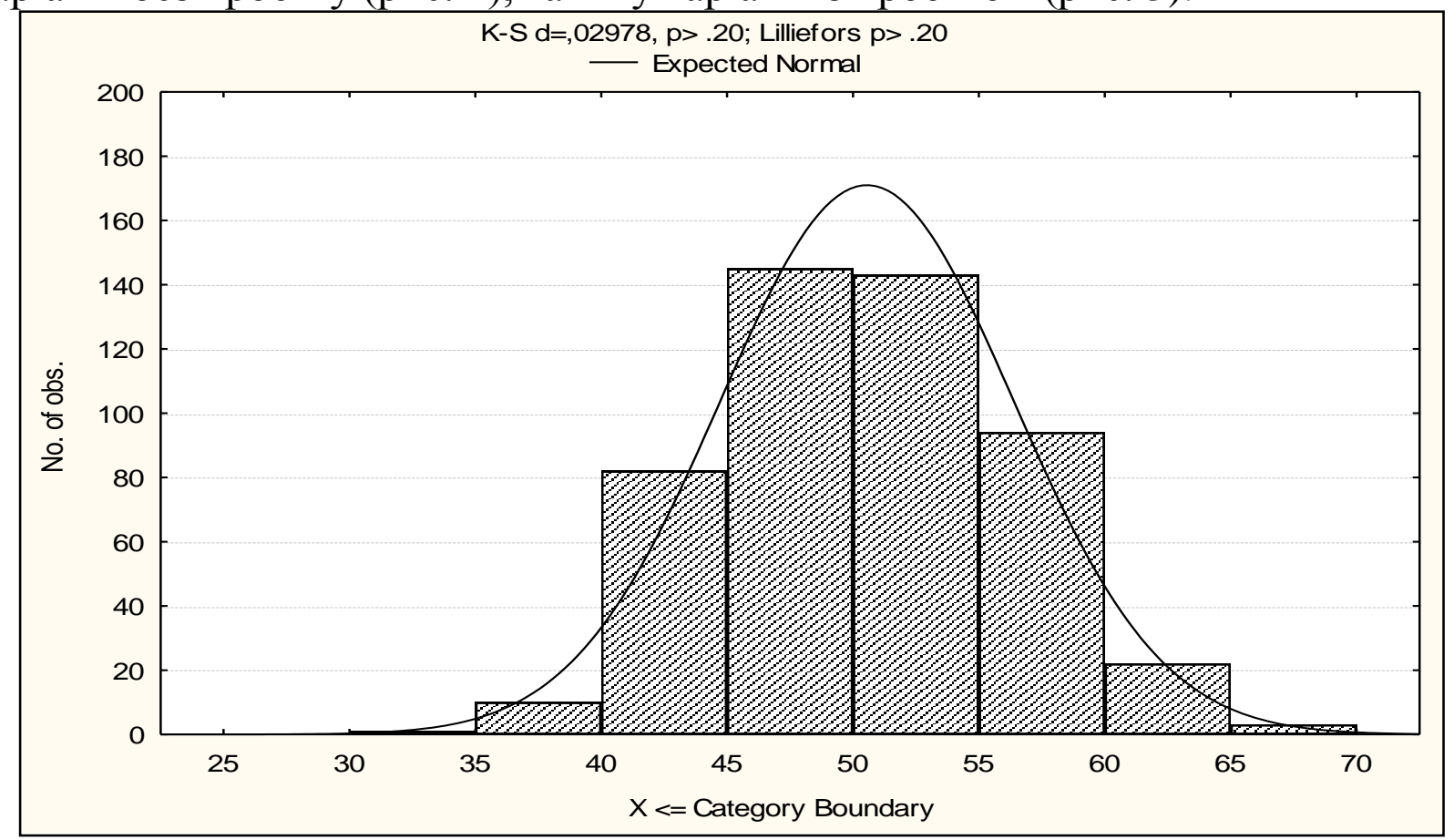

Рис. 2. Гістограма нормального розподілу врожайності сільськогосподарських культур від проведеної імітації по сівозміні для варіанта № 1 (контроль, без зрошення)

Джерело: побудовано авторами. 


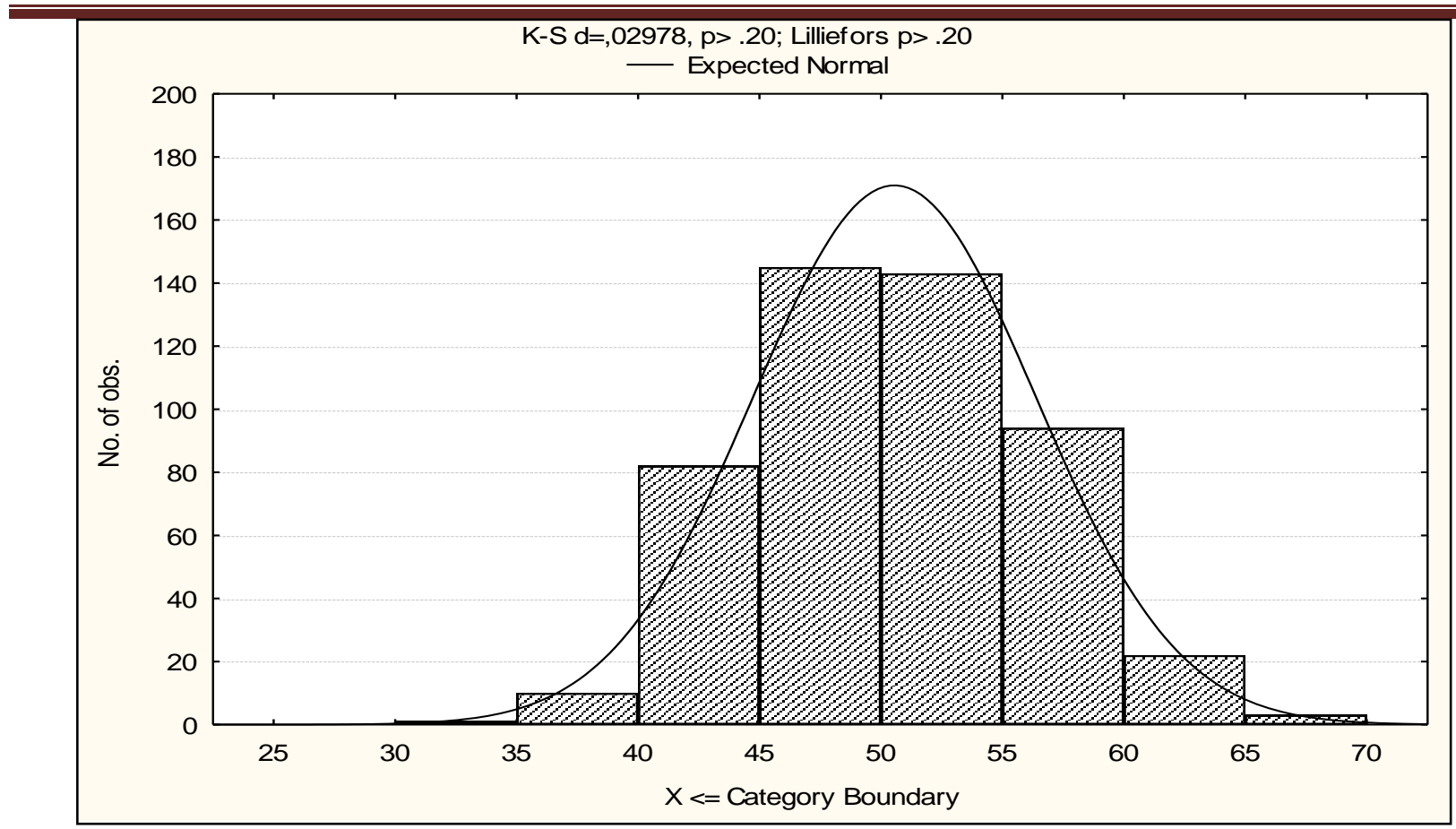

Рис. 3. Гістограма нормального розподілу врожайності

сільськогосподарських культур від проведеної імітації по сівозміні для варіанта № 2 (зрошення мінералізованою водою)

Джерело: побудовано авторами.

Аналіз зведених результатів імітаційного моделювання врожайності досліджуваних сільськогосподарських культур і в цілому по сівозміні за варіантом № 1 (табл. 6) і за варіантом № 2 (табл. 7), свідчить про статистичну достовірність одержаних результатів i відносно вищу технологічну ефективність другого варіанта порівняно з першим.

Табличя 6

Імітаційний аналіз (за методотом Монте-Карло) урожайності сільськогосподарських культур (ц/га) і в цілому по сівозміні (ц зерн. од./га) за варіантом № 1 (контроль, без зрошення), 2009-2017 рp.

\begin{tabular}{|c|c|c|c|c|c|c|c|c|c|c|}
\hline Пок & 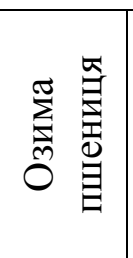 & 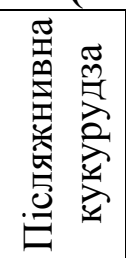 & 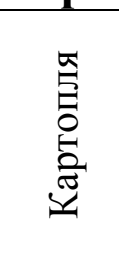 & 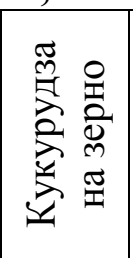 & 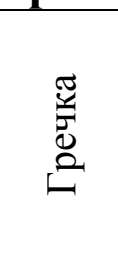 & 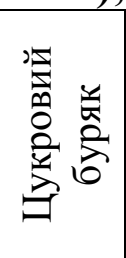 & 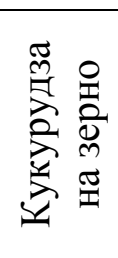 & 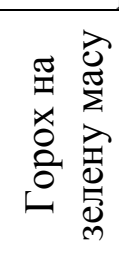 & 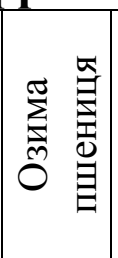 & 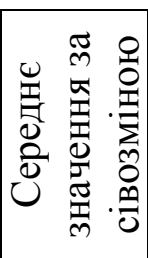 \\
\hline Середн & 60,4 & 32,2 & 50,6 & 59,0 & 8,7 & 498 & 89,1 & 222,8 & 58,7 & 50,6 \\
\hline $\begin{array}{l}\text { Стандар } \\
\text { лення (I }\end{array}$ & 0,9 & 1,8 & 5,3 & 7,8 & 2,3 & 434 & 17,5 & 53,6 & 3,9 & 5,8 \\
\hline Коефіці & 0,015 & 0,056 & 0,106 & 0,133 & 0,259 & 0,087 & 0,196 & 0,241 & 0,067 & 0,115 \\
\hline Мінімум & 57,6 & 26,5 & 33,6 & 34,1 & 1,6 & 360,6 & 33,8 & 53,1 & 46,2 & 32,1 \\
\hline Максил & 63,2 & 37,8 & 67,2 & 83,4 & 15,8 & 633,0 & 143,5 & 389,8 & 71,0 & 68,7 \\
\hline $\mathrm{P}(\mathrm{E}<=0)$ & 0,000 & 0,000 & 0,000 & 0,000 & 0,000 & 0,000 & 0,000 & 0,000 & 0,000 & 0,000 \\
\hline $\mathrm{P}(\mathrm{E}<=\mathrm{MII}$ & 0,0008 & 0,0008 & 0,0008 & 0,0008 & 0,0008 & 0,0008 & 0,0008 & 0,0008 & 0,0008 & 0,0008 \\
\hline $\mathrm{P}(\mathrm{M}(\mathrm{E})+$ & 0,158 & 0,158 & 0,158 & 0,158 & 0,158 & 0,158 & 0,158 & 0,158 & 0,158 & 0,158 \\
\hline $\mathrm{P}(\mathrm{M}(\mathrm{E})-\mathrm{s}<=\mathrm{E}<=\mathrm{M}(\mathrm{E}))$ & 0,341 & 0,341 & 0,341 & 0,341 & 0,341 & 0,341 & 0,341 & 0,341 & 0,341 & 0,341 \\
\hline
\end{tabular}


Імітаційний аналіз (за методом Монте-Карло) урожайності сільськогосподарських культур (ц/га) і в цілому по сівозміні (ц зерн. од./га) за варіантом № 2 (зрошення мінералізованою водою), 2009-2017 pp.

\begin{tabular}{|c|c|c|c|c|c|c|c|c|c|c|}
\hline 1 & 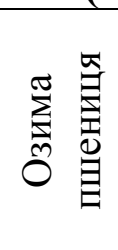 & 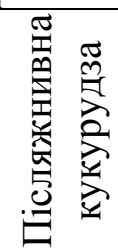 & 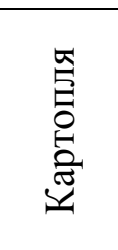 & 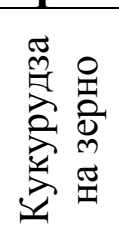 & 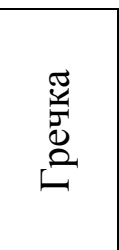 & 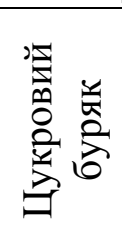 & 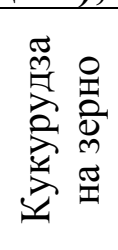 & 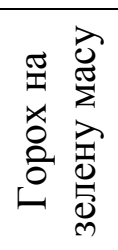 & 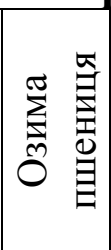 & 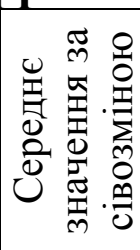 \\
\hline & 6,2 & 35,6 & 52,5 & 75,9 & & 575,7 & 3 & 32,7 & U & 577 \\
\hline & 1,1 & 1,0 & 1,7 & 3,7 & 25 & 69,3 & 14,9 & 451 & 2,3 & 5,4 \\
\hline Koec & 017 & 029 & 032 & 49 & 0,173 & 0,120 & 0,161 & 159 & 0,036 & 0,094 \\
\hline $\mathrm{Mi}$ & & 32,3 & 47,2 & & & 356,1 & 45,3 & 139,9 & 55,6 & 40,5 \\
\hline $\mathrm{Ma}$ &, 7 & 38,9 & 7,7 & 87,6 & 2,0 & 791,6 & 138,6 & 423,2 & 70,0 & 74,6 \\
\hline & 000 & 000 & 000 & 0,000 & 00 & 0,000 & 0,000 & 0,000 & 0,000 & 0,000 \\
\hline $\mathrm{P}(\mathrm{H}$ & 0008 & 0008 & 0,0008 & 0,0008 & 0,0008 & 0,0008 & 0,0008 & 0,0008 & 0,0008 & 0,0008 \\
\hline $\mathrm{P}(\mathrm{M}(\mathrm{E})$ & 0,158 & 0,158 & 158 & 0,158 & 0,158 & 0,158 & 0,158 & 0,158 & 0,158 & 0,158 \\
\hline $\mathrm{P}(\mathrm{M}(\mathrm{E})-\mathrm{s}<=\mathrm{E}<=\mathrm{M}(\mathrm{E}$ & 0,341 & 0,341 & 0,341 & 0,341 & 0,341 & 0,341 & 0,341 & 0,341 & 0,341 & 0,341 \\
\hline
\end{tabular}

Джерело: авторські розрахунки.

Однак, економічна ефективність виявилася не завжди на достатньому рівні, про що свідчать результати розрахунку додаткового прибутку (збитку) від приросту врожаю порівняно 3 контролем на 1 га площі (табл. 8).

Таблиия 8

Розрахунок додаткового прибутку (збитку) від приросту врожайності за мінімального значення порівняно $з$ контролем на 1 га посівної площі та на сівозміну, 2009-2017 pp.

\begin{tabular}{|l|c|c|c|}
\hline \multicolumn{1}{|c|}{ Культури } & \multicolumn{3}{|c|}{ Показники } \\
\cline { 2 - 4 } & $\begin{array}{c}\text { Додаткові витрати } \\
\text { за приростом } \\
\text { урожайності, } \\
\text { грн/га }\end{array}$ & $\begin{array}{c}\text { Додатковий дохід за } \\
\text { приростом } \\
\text { урожайності, грн/га }\end{array}$ & $\begin{array}{c}\text { Додатковий } \\
\text { прибуток (збиток) } \\
\text { за зміною } \\
\text { врожайності, грн/га }\end{array}$ \\
\hline Пшениця озима & 3525 & 3128 & -397 \\
\hline Післяжнивна кукурудза & 1069 & 382 & -687 \\
\hline Картопля & 4126 & 4484 & 358 \\
\hline Кукурудза на зерно & 12256 & 13161 & 905 \\
\hline Гречка & 2761 & 3441 & -3584 \\
\hline Цукровий буряк & 3218 & -366 & 1720 \\
\hline Кукурудза на зерно & 3345 & 5065 & -51 \\
\hline Горох на зелену масу & 3527 & 3476 & 2026 \\
\hline Пшениця озима & 3716 & 5742 & 108 \\
\hline $\begin{array}{l}\text { Середнє значення за } \\
\text { сівозміною }\end{array}$ & 4171 & 4279 & \\
\hline
\end{tabular}

Джерело: авторські розрахунки.

Отже, у випадку мінімального приросту врожайності від зрошення мінералізованою водою найбільшого додаткового прибутку можна досягти під час вирощування зерна пшениці озимої, посіяної після гороху на зелену масу 


\section{Agricultural and Resource Economics}

www.are-journal.com

(2026 грн/га), кукурудзи на зерно після буряка цукрового (1720 грн/га) та після картоплі (905 грн/га) за середнього значення по сівозміні на рівні 108 грн/га. Водночас вирощування буряка цукрового, післяжнивної кукурудзи, пшениці озимої та гороху на зелену масу виявилося економічно неефективним за критерієм додаткового прибутку на 1 га відповідної площі. Отже, результати дослідження, по-перше, підтверджують недостатню економічну ефективність зрошення обмежено придатною водою в умовах Донецької області; по-друге, вказують на необхідність застосування заходів щодо поліпшення якості води та/або додаткових меліоративних заходів, спрямованих на поліпшення якості грунту й умов живлення рослин, що потребує додаткових досліджень. Результати імітаційного моделювання врожайності сільськогосподарських культур в умовах зрошення можуть бути використані аграрними підприємствами під час управління проєктними ризиками.

Висновки. У результаті дослідження запропоновано концептуальну модель управління зрошувальними проєктами в контексті змін клімату, в основу якої варто покласти такі концептуальні ідеї: спрямованість на адаптацію до змін клімату шляхом кліматично розумного сталого землеробства (climatesmart agriculture); зміщення пріоритетів у напрямі індустрії 4.0 (industry 4.0). Дістали дальшого розвитку положення щодо еколого-економічної ефективності застосування меліоративних проєктів з урахуванням якості зрошувальної води.

У результаті лабораторного аналізу здійснено оцінку якості води, яка може бути використана для зрошення в конкретному державному аграрному підприємстві. На основі виконаного SWOT-аналізу обгрунтовано переваги проєкту організації виробництва аграрної продукції в умовах краплинного зрошення, оцінено інвестиційну привабливість цього проєкту. Доведено, що застосування краплинного зрошення сприяє зростанню не лише економічного ефекту, а й адаптації до зміни клімату. Найбільш ефективним може бути краплинне зрошення під час вирощування огірків, тоді як краплинне зрошення сої може виявитися неефективним за поточних умов інвестування. Основні результати дослідження можуть бути використані аграрними підприємствами під час управління зрошувальними проєктами.

Здійснено оцінку економічної ефективності застосування зрошення в землеробстві обмежено придатною водою під час вирощування різних сільськогосподарських культур. 3 огляду на економічну оцінку, вирощування більшості культур в умовах зрошення обмежено придатною водою виявилося малоефективним. Отже, є потреба в пошуку резервів іiі підвищення, наприклад, шляхом застосування заходів щодо поліпшення якості води та/або додаткових меліоративних заходів, спрямованих на поліпшення якості грунту й умов живлення рослин, що потребує додаткових досліджень у перспективі.

Одним із перспективних інноваційних напрямів підвищення ефективності краплинного зрошення може бути використання сонячних батарей, що належить до числа пріоритетних напрямів майбутніх наукових досліджень у контексті змін клімату й розвитку альтернативної енергетики. 


\section{Список використаних джерел}

1. Fuentes-Penna A., Ruiz-Vanoye J. A., Díaz-Parra O. Project management for farm production. International Journal of Combinatorial Optimization Problems and Informatics. 2017. Vol. 8. No. 3. Pp. 39-44.

2. Кучер Л. Ю. Концептуальний підхід до економічного управління інноваційними проектами аграрних підприємств. Вісник економічної науки України. 2016. № 2. С. 103-106.

3. Кучер Л. Упровадження інвестиційно-інноваційних проектів в агробізнесі. Agricultural and Resource Economics. 2017. Vol. 3. No. 2. Pp. 88-108. URL: http://are-journal.com.

4. Присяжнюк О., Плотнікова М. Удосконалення моделі управління аграрними проектами. Agricultural and Resource Economics. 2017. Vol. 3. No. 1. Pp. 164-172. URL: http://are-journal.com.

5. Тимочко В., Падюка Р. Можливості використання систем автоматизації управління проектами для умов сільськогосподарського виробництва. СхідноЄвропейський журнал передових технологій. 2013. Vol. 3. o. 3(63). Pp. 26-28.

6. Кучер Л., Хелдак М., Орленко А. Управління проектами в органічному аграрному виробництві. Agricultural and Resource Economics. 2018. Vol. 4. No. 3. Pp. 104-128. URL: http://are-journal.com.

7. Салимбаева Р. А. Проектное управление производством экологически чистой продукции в Казахстане. Central Asian Economic Review. 2019. Vol. 5. No. 128. Pp. 115-124.

8. Фесенко Т. Г., Фесенко Г. В., Фесенко Г. Г. Концептуальна модель офісу управління проектами органічного виробництва. Управління розвитком складних систем. 2016. Вип. 27. С. 92-100.

9. Rani P., Singh A. Evaluation of benchmarking indicators of Sanjay Sarovar irrigation project, India. Sustainable Water Resources Management. 2018. Vol. 4. Pp. 425-432. https://doi.org/10.1007/s40899-017-0122-7.

10. Kucher A., Anisimova O., Heldak M. Efficiency of Land Reclamation Projects: New Approach to Assessment for Sustainable Soil Management. Journal of Environmental Management and Tourism. 2019. Vol. 10. No. 7. Pp. 1568-1582. https://doi.org/10.14505//jemt.10.7(39).14.

11. Kucher A. V. Efficiency of organic land use. Agricultural and Resource Economics. 2017. Vol. 3. Is. 3. Pp. 41-62. URL: http://are-journal.com.

12. Kucher A. Sustainable soil management in the formation of competitiveness of agricultural enterprises. Plovdiv: Academic publishing house «Talent», 2019. 444 p. https://doi.org/10.13140/RG.2.2.19554.07366.

13. Кучер А. В., Анісімова О. В., Улько С. М. Ефективність інновацій для раціонального використання грунтів: теорія, методика, аналіз: моногр.; за ред. чл.-кор. АЕНУ А. В. Кучера. Харків: ФОП Бровін О. В., 2017. 275 с.

14. Кучер А. В., Анісімова О. В. Теоретичні аспекти визначення економічної ефективності застосування грунтоохоронних інновацій. Вісник аграрної науки. Спец. випуск. 2016. № 10. С. 87-91. 


\section{Agricultural and Resource Economics}

www.are-journal.com

15. Витоптова В. А., Бондаренко Н. А. Еколого-економічні особливості крапельного зрошення. Наукові прачі Кіровоградського національного технічного університету. Економічні науки. 2010. Вип. 18(1). С. 214-219.

16. Majumdar D. K. Irrigation water management: principles and practice. New Delhi: PHI Learning Private Limited, 2010. 487 p.

17. Меліорація грунтів (систематика, перспективи, інноваціi): кол. моногр. / за ред. С. А. Балюка, І. М. Ромащенка, Р. С. Трускавецького. Херсон: Грінь Д. С., 2015. 668 с.

18. Ромащенко М. I. Мікро зрошення сільськогосподарських культур. Меліорація і водне господарство. 2004. Вип. 90. С. 63-86.

19. Zou X., Li Y., Gao Q., Wan Yu. How water saving irrigation contributes to climate change resilience - a case study of practices in China. Mitigation and Adaptation Strategies for Global Change. 2012. Vol.17. Pp.111-132. https://doi.org/10.1007/s11027-011-9316-8.

20. Кучер А. Адаптація аграрного землекористування до змін клімату. Agricultural and Resource economics. 2017. Vol.3. No. 1. Pp. 119-138. URL: http://are-journal.com.

21. Cui Y. L., Tan F., Zheng C. J. Analysis of irrigation efficiency and water saving potential at different scales. Advances in Water Science. 2010. Vol. 21. Is. 6. Pp. 788-794. https://doi.org/10.1007/s11027-011-9316-8.

22. Negasa Y. T. Water use efficiency of smallholder farmers' irrigation scheme and its consequences on lake Hawassa. International Journal of Agriculture and Forestry. 2020. Vol. 10. No. 1. Pp. 1-10. https://doi.org/10.5923/j.ijaf.20201001.01.

23 Клепіков О. Д., Антоненко Т. Я. Вплив гідромеліораційних заходів на продуктивність сільгоспугідь. Продуктивність агропромислового виробництва. 2017. № 29. С. 57-61.

24. Фомічов М. В. Зрошення як чинник підвищення ефективності вирощування сільськогосподарських культур в Україні. Економіка та держава. 2019. № 4. C. 92-96. https://doi.org/10.32702/2306-6806.2019.4.92.

25. Кисляченко М. Ф. Ефективність крапельного зрошення картоплі та овочевих культур в Україні. Продуктивність агропромислового виробництва. Економічні науки. 2014. Вип. 25. С. 102-107.

26. Gebremariam H. L., Welde K., Kahsay K. D. Optimizing yield and water use efficiency of furrow-irrigated potato under different depth of irrigation water levels. Sustainable Water Resources Management. 2018. Vol. 4. Pp. 1043-1049. https://doi.org/10.1007/s40899-018-0238-4.

27. Welde K., Gebremariam H. L., Kahsay K. D. Optimizing irrigation water levels to improve yield and water use efficiency of vegetables: case study of tomato. Sustainable Water Resources Management. 2019. Vol. 5. Pp.737-742. https://doi.org/10.1007/s40899-018-0250-8.

28. Chauhan J. S., Kumar S. Wastewater ferti-irrigation: an eco-technology for sustainable agriculture. Sustainable Water Resources Management. 2020. Vol. 6. 31. https://doi.org/10.1007/s40899-020-00389-5. 


\section{Agricultural and Resource Economics}

www.are-journal.com

29. Hassani Y., Hashemy Shahdany S. M., Maestre J. M., Zahraie B., Ghorbanif M., Henneberryg S. R., Kulshreshthah S. N. An economic-operational framework for optimum agricultural water distribution in irrigation districts without water marketing. Agricultural Water Management. 2019. Vol. 221. Pp. 348-361. https://doi.org/10.1016/j.agwat.2019.05.012.

30. Li H., Zhao J. Rebound Effects of new irrigation technologies: the role of water rights. American Journal of Agricultural Economics. 2018. Vol. 100. Is. 3. Pp. 786-808. https://doi.org/10.1093/ajae/aay001.

31. Mesa-Juradoa M. A., Martin-Ortegab J., Rutoc E., Berbeld J. The economic value of guaranteed water supply for irrigation under scarcity conditions. Agricultural Water Management. 2012. Vol. 113. Pp. 10-18. https://doi.org/10.1016/j.agwat.2012.06.009.

32. García Suárez F., Fulginiti L. E., Perrin R. K. What Is the Use Value of Irrigation Water from the High Plains Aquifer? American Journal of Agricultural Economics. 2019. Vol. 101. Is. 2. Pp. 455-466. https://doi.org/10.1093/ajae/aay062.

33. Li M., Xu W., Zhu T. Agricultural Water Allocation under Uncertainty: Redistribution of Water Shortage Risk. American Journal of Agricultural Economics. 2019. Vol. 101. Is. 1. Pp. 134-153. https://doi.org/10.1093/ajae/aay058.

34. Sampson G. S., Perry E. D. The Role of Peer Effects in Natural Resource Appropriation - The Case of Groundwater. American Journal of Agricultural Economics. 2019. Vol. 101. Is. 1. Pp. 154-171. https://doi.org/10.1093/ajae/aay090.

35. Koech R., Langat P. Improving irrigation water use efficiency: a review of advances, challenges and opportunities in the Australian context. Water. 2018. Vol. 10. Is. 12. 1771. https://doi.org/10.3390/w10121771.

36. Fernándeza J. E., Alconb F., Diaz-Espejoa A., Hernandez-Santanaa V., Cuevasa M. V. Water use indicators and economic analysis for on-farm irrigation decision: A case study of a super high density olive tree orchard. Agricultural Water Management. 2020. Vol. 237. 106074. https://doi.org/10.1016/j.agwat.2020.106074.

37. Laureti T., Benedetti I., Branca G. Water use efficiency and public goods conservation: a spatial stochastic frontier model applied to irrigation in Southern $\begin{array}{llll}\text { Italy. Socio-Economic Planning } & \text { Sciences. } & 100856 .\end{array}$ https://doi.org/10.1016/j.seps.2020.100856.

38. Osewe M., Liu A., Njagi T. Farmer-led irrigation and its impacts on smallholder farmers' crop income: Evidence from Southern Tanzania. International Journal of Environmental Research and Public Health. 2020. Vol. 17. Is. 5. 1512. https://doi.org/10.3390/ijerph17051512.

39. Tan Q., Zhang S., Li R. Optimal use of agricultural water and land resources through reconfiguring crop planting structure under socioeconomic and ecological objectives. Water. 2017. Vol. 9. Is. 7. 488. https://doi.org/10.3390/w9070488.

40. García I. F., Lecina S., Ruiz-Sánchez M. C., Vera J. et al. Trends and challenges in irrigation scheduling in the Semi-Arid area of Spain. Water. 2020. Vol. 12. Is. 3. 785. https://doi.org/10.3390/w12030785.

41. Monteleone S. de Moraes E. A., Maia R. F. Analysis of the variables that 
affect the intention to adopt Precision Agriculture for smart water management in Agriculture 4.0 context. Global IoT Summit (GIoTS), Aarhus, Denmark, 2019. Pp. 16. https://doi.org/10.1109/GIOTS.2019.8766384.

42. Yohannes D. F. Innovative irrigation water management: a strategy to increase yield and reduce salinity hazard of small scale irrigation in Ethiopia. Wageningen: Wageningen University, 2020. 163 p. https://doi.org/10.18174/506355.

43. Li Y., Hu J., Di W., Zhang L., Suman D. O., Zhu H. Success factors of irrigation projects based on a "public-private partnership» model in a mountainous area: a case study in the nujiang River Valley, China. Sustainability. 2019. Vol. 11. Is. 23. 6799. https://doi.org/10.3390/su11236799.

\section{References}

1. Fuentes-Penna, A., Ruiz-Vanoye, J. A. and Díaz-Parra, O. (2017), Project Management for Farm Production. International Journal of Combinatorial Optimization Problems and Informatics, vol. 8, no. 3, pp. 39-44.

2. Kucher, L. Yu. (2016), Conceptual approach to economic management of innovative projects of agricultural enterprises. Visnyk ekonomichnoi nauky Ukrainy, no. 2, pp. 103-106.

3. Kucher, L. (2017), Implementation of investment-innovation projects in agribusiness. Agricultural and Resource Economics, vol. 3, no. 2, pp. 88-108, available at: http://are-journal.com.

4. Prysiazhniuk, O. and Plotnikova, M. (2017), Improving the model of agricultural project management. Agricultural and Resource Economics, vol. 3, no. 1, pp. 164-172, available at: http://are-journal.com.

5. Tymochko, V. and Padiuka, R. (2013), Possibilities of using project management automation systems for agricultural production. Skhidno-Ievropeiskyi zhurnal peredovykh tekhnolohii, vol. 3, no. 3(63), pp. 26-28.

6. Kucher, L., Heldak, M. and Orlenko, A. (2018), Project management in organic agricultural production. Agricultural and Resource Economics, vol. 4, no. 3, pp. 104-128, http://are-journal.com.

7. Salimbaeva, R. A. (2019), Project management of the production of environmentally friendly products in Kazakhstan. Central Asian Economic Review, vol. 5, no. 128, pp. 115-124.

8. Fesenko, T., Fesenko, H. and Fesenko, H. (2016), Conceptual model of office management of organic product projects. Upravlinnia rozvytkom skladnykh system, vol. 27, pp. 92-100.

9. Rani, P. and Singh, A. (2018), Evaluation of benchmarking indicators of Sanjay Sarovar Irrigation Project, India. Sustainable Water Resources Management, vol. 4, pp. 425-432. https://doi.org/10.1007/s40899-017-0122-7.

10. Kucher, A., Anisimova, O. and Heldak, M. (2019), Efficiency of land reclamation projects: new approach to assessment for sustainable soil management. Journal of Environmental Management and Tourism, vol. 10, no. 7, pp. 1568-1582. https://doi.org/10.14505//jemt.10.7(39).14. 
11. Kucher, A. V. (2017), Efficiency of organic land use. Agricultural and Resource Economics, vol. 3, is. 3, pp. 41-62. URL: http://are-journal.com.

12. Kucher, A. (2019), Sustainable soil management in the formation of competitiveness of agricultural enterprises. Academic publishing house «Talent», Plovdiv, Bulgaria. https://doi.org/10.13140/RG.2.2.19554.07366.

13. Kucher, A. V., Anisimova, O. V. and Ulko, Ye. M. (2017), Efficiency of innovations for sustainable soil management: theory, methodology, analysis. Publisher Brovin, Kharkiv, Ukraine.

14. Kucher, A. and Anisimova, O. (2016), Theoretical aspects of definition of economic efficiency of application of soil-protecting innovations. News of agrarian sciences. Special issue, no. 10, pp. 87-91.

15. Vytoptova, V. A. and Bondarenko, N. A. (2010), Ecological and economic features of drip irrigation. Naukovi pratsi Kirovohradskoho natsionalnoho tekhnichnoho universytetu. Ekonomichni nauky, vol. 18(1), pp. 214-219.

16. Majumdar, D. K. (2010), Irrigation water management: principles and practice. New PHI Learning Private Limited, Delhi, India.

17. Baliuk, S. A., Romashchenko, M. I. and Truskavetskyi, R. S. eds. (2015), Melioratsiia gruntiv (systematyka, perspektyvy, innovatsii) [Reclamation of soils (systematics, perspectives, innovation)], Hrin D. S., Kherson, Ukraine.

18. Romashchenko, M. I. (2004), Micro irrigation of agricultural crops. Melioratsiia $i$ vodne hospodarstvo, vol. 90, pp. 63-86.

19. Zou, X., Li, Y., Gao, Q. and Wan, Yu. (2012), How water saving irrigation contributes to climate change resilience - a case study of practices in China. Mitigation and Adaptation Strategies for Global Change, vol. 17, pp. 111-132. https://doi.org/10.1007/s11027-011-9316-8.

20. Kucher, A. (2017), Adaptation of the agricultural land use to climate change. Agricultural and Resource Economics, vol. 3, no. 1, pp.119-138, available at: http://are-journal.com.

21. Cui, Y. L., Tan, F. and Zheng, C. J. (2010), Analysis of irrigation efficiency and water saving potential at different scales. Advances in Water Science, vol. 21, is. 6, pp. 788-794. https://doi.org/10.1007/s11027-011-9316-8.

22. Negasa, Y. T. (2020), Water Use Efficiency of Smallholder Farmers' Irrigation Scheme and Its Consequences on Lake Hawassa. International Journal of Agriculture and Forestry, vol. 10, no. 1, pp. 1-10. https://doi.org/10.5923/j.ijaf.20201001.01.

23. Klepikov, A. D. and Antohenko, T. J. (2017), Influence of events of water conservation is on the productivity of farmlands. Produktyvnist ahropromyslovoho vyrobnytstva, no. 29, pp. 57-61.

24. Fomichov, M. (2019), Irrigation as the factor enhancing the efficiency of agricultural crops production in Ukraine. Ekonomika ta derzhava, vol. 4, pp. 92-96. https://doi.org/10.32702/2306-6806.2019.4.92.

25. Kisliachenko, M. (2014), Efficiency drip irrigation of potato and vegetable crops in Ukraine. Produktyvnist ahropromyslovoho vyrobnytstva. Ekonomichni 
nauky, vol. 25, pp. 102-107.

26. Gebremariam, H. L., Welde, K. and Kahsay, K. D. (2018), Optimizing yield and water use efficiency of furrow-irrigated potato under different depth of irrigation water levels. Sustainable Water Resources Management, vol. 4, pp. 1043-1049. https://doi.org/10.1007/s40899-018-0238-4.

27. Welde, K., Gebremariam, H. L. and Kahsay, K. D. (2019), Optimizing irrigation water levels to improve yield and water use efficiency of vegetables: case study of tomato. Sustainable Water Resources Management, vol. 5, pp. 737-742. https://doi.org/10.1007/s40899-018-0250-8.

28. Chauhan, J. S. and Kumar, S. (2020), Wastewater ferti-irrigation: an ecotechnology for sustainable agriculture. Sustainable Water Resources Management, vol. 6, 31. https://doi.org/10.1007/s40899-020-00389-5.

29. Hassani, Y., Hashemy Shahdany, S. M., Maestre, J. M., Zahraie, B., Ghorbanif, M., Henneberryg, S. R. and Kulshreshthah, S. N. (2019), An economicoperational framework for optimum agricultural water distribution in irrigation districts without water marketing. Agricultural Water Management, vol. 221, pp. 348-361. https://doi.org/10.1016/j.agwat.2019.05.012.

30. Li, Y., Hu, J., Di, W., Zhang, L., Suman, D. O. and Zhu, H. (2019), Success factors of irrigation projects based on a «public-private partnership» model in a mountainous area: A case study in the nujiang River Valley, China. Sustainability, vol. 11, is. 23, 6799. https://doi.org/10.3390/su11236799.

31. Mesa-Juradoa, M. A., Martin-Ortegab, J., Rutoc, E. and Berbeld, J. (2012), The economic value of guaranteed water supply for irrigation under scarcity conditions. Agricultural Water Management, vol. 113, pp. 10-18. https://doi.org/10.1016/j.agwat.2012.06.009.

32. García Suárez, F., Fulginiti, L. E. and Perrin, R. K. (2019), What Is the Use Value of Irrigation Water from the High Plains Aquifer? American Journal of Agricultural Economics, vol. 101, is. 2, pp. 455-466. https://doi.org/10.1093/ajae/aay062.

33. Li, M., Xu, W. and Zhu, T. (2019), Agricultural water allocation under uncertainty: redistribution of water shortage risk. American Journal of Agricultural Economics, vol. 101, is. 1, pp. 134-153. https://doi.org/10.1093/ajae/aay058.

34. Sampson, G. S. and Perry, E. D. (2019), The role of peer effects in natural resource appropriation - the case of groundwater. American Journal of Agricultural Economics, vol. 101, is. 1, pp. 154-171. https://doi.org/10.1093/ajae/aay090.

35. Koech, R. and Langat, P. (2018), Improving irrigation water use efficiency: a review of advances, challenges and opportunities in the Australian context. Water, vol. 10, is. 12, 1771. https://doi.org/10.3390/w10121771.

36. Fernándeza, J. E., Alconb, F., Diaz-Espejoa, A. and Hernandez-Santanaa, V. and Cuevasa, M. V. (2020), Water use indicators and economic analysis for on-farm irrigation decision: A case study of a super high density olive tree orchard. $\begin{array}{llll}\text { Agricultural Water } \quad \text { Management, } & & & \end{array}$ https://doi.org/10.1016/j.agwat.2020.106074. 


\section{Agricultural and Resource Economics}

www.are-journal.com

37. Laureti, T., Benedetti, I. and Branca, G. (2020), Water use efficiency and public goods conservation: A spatial stochastic frontier model applied to irrigation in Southern Italy. Socio-Economic Planning Sciences, 100856. https://doi.org/10.1016/j.seps.2020.100856.

38. Osewe, M., Liu, A. and Njagi, T. (2020), Farmer-Led Irrigation and its Impacts on Smallholder Farmers' Crop Income: Evidence from Southern Tanzania. International Journal of Environmental Research and Public Health, vol. 17, is. 5, 1512. https://doi.org/10.3390/ijerph17051512.

39. Tan, Q., Zhang, S. and Li, R. (2017), Optimal Use of Agricultural Water and Land Resources through Reconfiguring Crop Planting Structure under Socioeconomic and Ecological Objectives. Water, vol. 9, is. 7, 488. https://doi.org/10.3390/w9070488.

40. García, I. F., Lecina, S., Ruiz-Sánchez, M. C. and Vera J. et al. (2020), Trends and Challenges in Irrigation Scheduling in the Semi-Arid Area of Spain. Water, vol. 12, is. 3, 785. https://doi.org/10.3390/w12030785.

41. Monteleone, S., de Moraes, E. A. and Maia, R. F. (2019), Analysis of the variables that affect the intention to adopt Precision Agriculture for smart water management in Agriculture 4.0 context. Global IoT Summit (GIoTS), Aarhus, Denmark. https://doi.org/10.1109/GIOTS.2019.8766384.

42. Yohannes, D. F. (2020), Innovative irrigation water management: a strategy to increase yield and reduce salinity hazard of small scale irrigation in Ethiopia. Wageningen University, Wageningen, Netherlands. https://doi.org/10.18174/506355.

43. Li, H. and Zhao, J. (2018), Rebound Effects of New Irrigation Technologies: The Role of Water Rights. American Journal of Agricultural Economics, vol. 100, is. 3, pp. 786-808. https://doi.org/10.1093/ajae/aay001.

How to cite this article? Як цитувати цю статтю?

Стиль-ДСТУ:

Кучер Л., Дрокін С., Улько С. Еколого-економічна ефективність зрошувальних проєктів у контексті змін клімату. Agricultural and Resource Economics. 2020. Vol. 6. No. 2. Pp. 57-77. URL: http://are-journal.com.

Style - Harvard:

Kucher L., Drokin S. and Ulko Y. (2020), Ecological-economic efficiency of irrigation projects in the context of climate change. Agricultural and Resource Economics, vol. 6, no. 2, pp. 57-77. URL: http://are-journal.com. 